\title{
Induced sputum for the investigation of airway inflammation: Evidence for its clinical application
}

\author{
Frederick E Hargreave MD FRCP FRCPC \\ Asthma Research Group, Department of Medicine, St Joseph's Hospital and \\ McMaster University, Hamilton, Ontario
}

FE Hargreave. Induced sputum for the investigation of airway inflammation: Evidence for its clinical application. Can Respir J 1999;6(2):169-174.

Airway inflammation is considered to be the primary cause of airway diseases. Its prevention and reversal are the primary aims of treatment. Measurement of the inflammation is now possible relatively noninvasively and reliably by using induced sputum cell counts. The differential count indicates the presence and type of the inflammation (eosinophilic or neutrophilic) and the total cell count the intensity. Sputum eosinophilia responds to treatment with corticosteroid, while there is increasing evidence that an isolated neutrophilia does not. Clinical judgement of airway inflammation is made difficult because of the different types of inflammation and their inconsistent correlation with the clinical features. Hence, reliable measurement of induced sputum cell counts may be useful to guide treatment in clinical practice. Consideration should now be given as to how to make it more available.

Key Words: Airway inflammation, Asthma treatment, Eosinophilic bronchitis, Induced sputum, Sputum cell counts

\section{Expectoration provoquée pour la recherche d'une inflammation des voies aériennes : preuves pour son application clinique}

RÉSUMÉ : L'inflammation des voies aériennes est considérée comme la cause principale des maladies pulmonaires. Sa prévention et sa réversion sont les principaux objectifs du traitement. La mesure de l'inflammation est maintenant possible, relativement peu sanglante et précise et fait appel à une numération des cellules de l'expectoration provoquée. La numération différentielle indique la présence et le type de l'inflammation (éosinophile ou neutrophile), et la numération totale des cellules, son intensité. L'éosinophilie révélée dans l'expectoration répond au traitement avec des corticostéroïdes, alors que de plus en plus de preuves démontrent que tel n'est pas le cas pour la neutrophilie isolée. Une appréciation clinique de l'inflammation des voies aériennes s'avère difficile à cause des différents types d'inflammation et de leur corrélation discordante avec les signes cliniques. Par conséquent, une mesure fiable de la numération des cellules de l'expectoration provoquée pourrait s'avérer utile pour guider le traitement en pratique clinique. Il faut désormais se pencher sur la manière de rendre cette méthode plus accessible.
A irway inflammation is considered to be the primary cause of airway diseases including asthma, the cause of asthma exacerbations, and the cause of persistent or progressive airway hyperresponsiveness and chronic airflow limitation. It is, therefore, responsible for acute or chronic symp- toms and physiological abnormalities. Prevention and reversal of the inflammation are considered to be primary aims of treatment. Thus, measurement of airway inflammation is important to understand airway diseases and their treatments better. The introduction of induced sputum ex-

Correspondence and reprints: Dr FE Hargreave, Firestone Regional Chest and Allergy Unit, St Joseph's Hospital, 50 Charlton Avenue East, Hamilton, Ontario L8N 4A6. Telephone 905-521-6000 ext 3714, fax 905-521-6158, e-mail hargreav@fhs.mcmaster.ca 

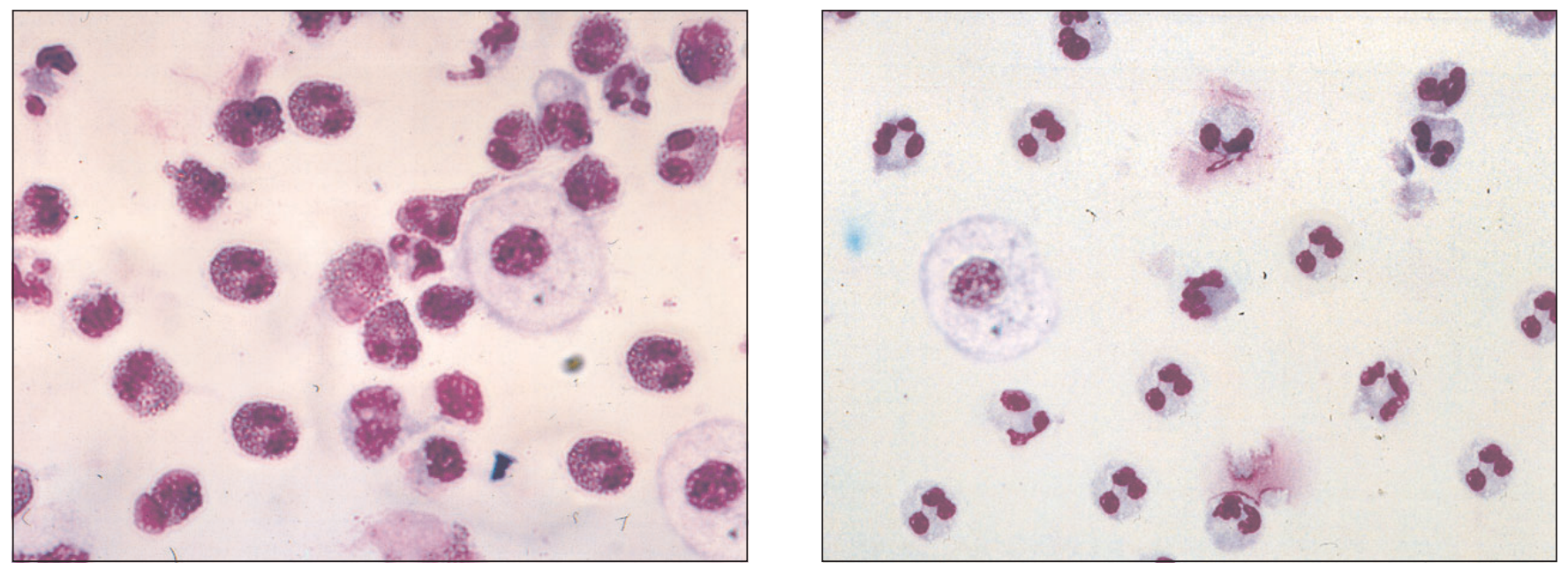

Figure 1) Left $A$ cytospin field with an excess of eosinophils from a subject with uncontrolled asthma. Right An excess of neutrophils from a subject with infective bronchitis

amination has made this possible (1). Because this technique is relatively noninvasive, it can be applied at random, in severe disease and repeatedly to examine the effects of treatment.

\section{MEASUREMENT OF AIRWAY INFLAMMATION}

Sputum is defined as lower respiratory tract secretions. It can be induced with an aerosol of hypertonic saline $(2,3)$. A short-acting beta2-agonist is inhaled to inhibit possible bronchoconstriction from the saline aerosol. The aerosol is generated by an ultrasonic nebulizer; we initially used the Fisoneb, which is no longer produced, and now use the Universal (Methapharm Inc), which is similar but improved. We use $3 \%, 4 \%$ and $5 \%$ concentrations of saline, each inhaled for 7 mins, although for a $3 \%$ or $4 \%$ concentration a shorter period may be sufficient. Forced expiratory volume in $1 \mathrm{~s}$ $\left(\mathrm{FEV}_{1}\right)$ is measured before and after each inhalation, or at any time if symptoms develop, for safety. The subject is asked to blow their nose, rinse their mouth and swallow water to limit contamination with postnasal drip and saliva, and to try to cough sputum into a container. The method is safe in patients with mild asthma $(4,5)$. It can be made safe in subjects with more severe asthma or chronic airflow limitation by beginning with normal saline and using shorter periods of inhalation (6,7). In clinical practice, the procedure can be discontinued when enough sputum is obtained. It is successful in $80 \%$ or more of adults and older children who are healthy or have airway disease.

The specimen of sputum needs to be processed as soon as possible, within $2 \mathrm{~h}$. It is an advantage if the cells can be preserved for longer, in case a specimen is collected at night or during the weekend; how to accomplish this is being investigated. When sputum is expectorated, it is often mixed with saliva. Some investigators examine the whole expectorate (8), but we select out the sputum from saliva with blunt forceps. This is then treated with $0.1 \%$ dithiothreitol, followed by saline, and filtered $(3,9)$. Dithiothreitol breaks disulphide bonds in the mucus and allows a uniform dispersal of the cells. A total cell count and cell viability are obtained by us- ing a hemocytometer and trypan blue stain, respectively. Cytospins are made and stained with Wright's stain, and a differential cell count is performed on 400 cells. The remaining suspension is centrifuged, and the fluid phase stored at $-70^{\circ} \mathrm{C}$ for later measurements, if these are required. However, for clinical practice, only cell counts are needed. The results can be obtained within 1 to $2 \mathrm{~h}$ and involve 30 to 40 mins of technologist time, with the remainder of the process being automated.

This method of sputum induction and examination has been evaluated. The cell counts in induced sputum are similar to those in spontaneous sputum (10). The selection of sputum from the expectorate is usually very successful at minimizing salivary contamination as indicated by less than $5 \%$ of squamous epithelial cells and improves the recognition of the types of nonsquamous cells (11). This is relevant because squamous contamination of greater than $20 \%$ is associated with poorer repeatability of nonsquamous counts (12). Clearly, the total cell count is reduced by selection and filtering, but measurements can be expressed per milligram of selected sputum and the differential cell count is not altered. The neutrophil, eosinophil and macrophage differential cell counts, and several of the fluid-phase measurements are reproducible (reliable) (9), valid and responsive $(6,13)$, but the total cell and lymphocyte counts are not as reliable as those. The cell counts obtained from sputum induction are different from the cell counts obtained from bronchial washings, bronchoalveolar lavage (BAL) and bronchial biopsies (14-18). This is to be expected given the different compartments being sampled. Eosinophils and neutrophils are highest in number in sputum, whereas macrophages and lymphocytes are higher in number in BAL. The predominant cell in biopsies is the lymphocyte. In a comparison of sputum versus blood eosinophils and serum eosinophylic cationic protein in patients with asthma, and a control group of healthy subjects and others with smokers' nonobstructive chronic bronchitis, sputum eosinophils and eosinophylic cationic protein were more sensitive and specific to the blood measurements (19). 
TABLE 1

Induced sputum: markers of inflammation

\begin{tabular}{lccc}
\hline & Healthy & Stable asthma & Smokers' bronchitis \\
\hline Total cells $\times 10^{6} / \mathrm{mg}$ & $3.1(4.0)$ & $3.3(6.0)$ & $3.9(3.5)$ \\
Percentage eosinophils & $0.5(1.1)$ & $5.2(19.4)$ & $0.3(0.7)$ \\
Percentage neutrophils & $24.1(26.8)$ & $46.9(42.0)$ & $33.0(27.2)$ \\
\hline
\end{tabular}

Data are median (interquartile range) (9). More comprehensive data on all counts in health subjects have been submitted for publication (unpublished data)

TABLE 2

Changes in clinical features and sputum cell counts in a patient with prednisone-dependent eosinophilic bronchitis

\begin{tabular}{|c|c|c|c|c|}
\hline RV $65 \mathrm{Y}$ & April 11 & April 18 & April 25 & June 7 \\
\hline Symptoms & 0 & 0 & 0 & + \\
\hline Forced expiratory volume in $1 \mathrm{~s}\left(\mathrm{FEV}_{1}\right)(\mathrm{L})$ & 1.9 & 1.9 & 1.6 & 1.3 \\
\hline Vital capacity $(\mathrm{L})$ & 2.7 & 2.5 & 2.3 & 1.9 \\
\hline $\begin{array}{l}\text { Provocation concentration of methacholine to cause } \\
\text { a fall in } F E V_{1} \text { of } 20 \%(\mathrm{mg} / \mathrm{mL})\end{array}$ & $>16$ & & $>16$ & $>16$ \\
\hline Percentage sputum eosinophils & 1.3 & 27.3 & 71.3 & 61.5 \\
\hline Prednisone (mg/day) (number of days on that dose) & $30(8)$ & $20(6)$ & $17.5(7)$ & $10(35)$ \\
\hline Budesonide (mg/day) & 3.2 & 3.2 & 3.2 & 3.2 \\
\hline
\end{tabular}

Prednisone was reduced progressively. + Cough and sputum

\section{RESEARCH OBSERVATIONS RELEVANT TO CLINICAL PRACTICE}

Sputum examination has drawn attention to the different types of airway inflammation and their causes; eosinophilic existence of bronchitis without asthma; asthma without an eosinophilic bronchitis; neutrophilic exacerbations of asthma; the frequent failure of clinical assessment to recognize the presence or type of inflammation in sputum and the influence of the type of inflammation on the effects of different treatments.

Sputum examination has emphasized the occurrence of different types of inflammation based on increases in specific cells and the different causes of these inflammations (Figure 1, Table 1). Eosinophilic inflammation is recognized to be a feature of asthma $(9,20)$, defined as a condition in which there is variable narrowing of the airways of the lungs (modified from Scadding [21]), sputum eosinophilia occur from airway reactions to allergens $(13,22)$ and occupational chemical sensitizers $(23,24)$ in sensitized subjects, and after withdrawal of corticosteroid treatment in steroid-dependent asthma (25). Neutrophilic inflammation occurs in cigarette smokers $(9,26)$, during bacterial and viral infections $(27)$, and after the inhalation of endotoxin (28) and some pollutants such as ozone (29). A sputum lymphocytosis has been observed early in a subject with cough associated with chlamydia infection (30). Many of these causes are common, and can occur at the same or different times in the same individual. The colour of the sputum can identify intense neutrophilia when it is mucopurulent or purulent, but not eosinophilia, which can occur in mucoid, mucopurulent or purulent sputum (31). The clinical significance of the different types of inflammation relates to differences in clinical and physiological presentation, and the effects of treatment.

Sputum examination was responsible for the recognition of eosinophilic bronchitis without asthma (32), which may be asymptomatic but can present with a chronic cough which can be dry or productive. Spirometry, diurnal variation of peak expiratory flow (PEF) and responsiveness to methacholine or adenosine monophosphate are normal (33). The sputum contains an increase in eosinophils and metachromatic cells, and mRNA for interleukin-5 and granulocyte-macrophage colony-stimulating factor as in eosinophilic bronchitis with asthma (34). Eosinophilic bronchitis without asthma occurs in atopic or nonatopic subjects, and may be caused by inhaled allergens or occupational chemical sensitizers (35). It may occur in smokers or nonsmokers, and be transient (36) or persistent and require regular treatment. If left untreated, airway hyperresponsiveness and other features of asthma may occur $(33,36)$, or there may be a progressive fall in $\mathrm{FEV}_{1}$ without airway hyperresponsiveness (37) (Table 2). The recognition of this cause of chronic cough is important with respect to treatment.

The examination of sputum has identified what has also been observed with BAL (38), that the severity of eosinophilic bronchitis does not necessarily correlate with the severity of clinical and physiological parameters in asthma $(32,39)$. There may be no eosinophilic bronchitis in a patient with many symptoms due to variable airflow limitation and severe airway hyperresponsiveness. In contrast, a pronounced eosinophilic bronchitis can occur in someone with only mild airway hyperresponsiveness. This may make it difficult to recognize the presence or severity of an eosinophilic bronchitis from clinical parameters.

An increase in the proportion of neutrophils in sputum is a feature of asthma (9). However, some exacerbations of asthma can be characterized by a more intense neutrophilia without an eosinophilia. The exacerbation can be mild (40), severe $(6,41)$ or fatal $(42)$. Causes of neutrophilic exacerbations include respiratory virus infection (27) and certain oc- 


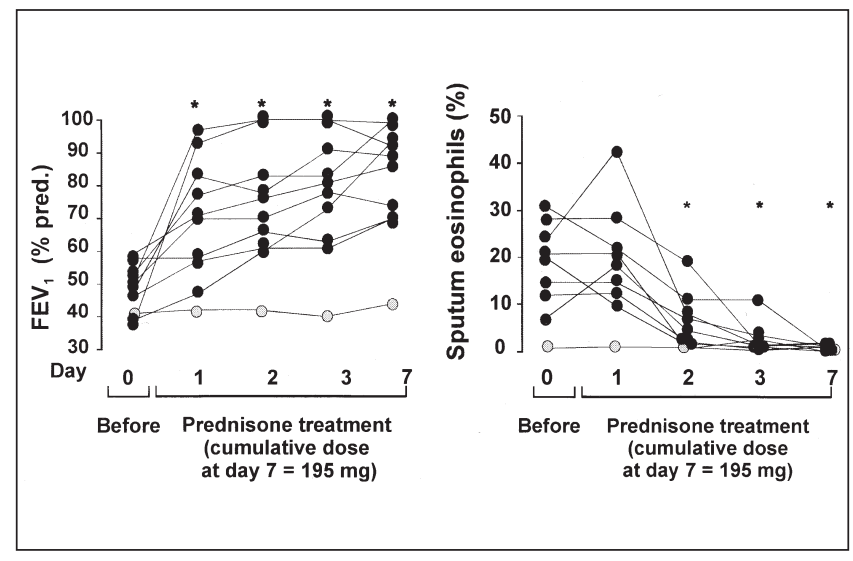

Figure 2) Left Postbronchodilator forced expiratory volume in $1 \mathrm{~s}$ $\left(F E V_{1}\right)$ (percentage predicted [pred.]) at presentation with a severe exacerbation of asthma on day 0 , and days 1,2,3 and 7 of treatment with prednisone for 10 patients. Right Proportion of eosinophils in induced sputum at the same times. Nine patients had sputum eosinphilia (more than 2\%) at presentation, and all were improved clinically by prednisone treatment; the one patient without eosinophilia did not improve (6). Improvement in sputum eosinophilia lagged behind improvement in $F E V_{l}$ * ${ }^{*} \leq 0.05$

cupational exposures $(43,44)$. How often neutrophilic exacerbations occur is unknown, but, if viral exacerbations of asthma are common, they also may be common.

Neutrophilic exacerbations respond differently than eosinophilic exacerbations to treatment. Sputum eosinophilia responds to treatment with corticosteroids whether the clinical presentation is of asthma $(6,37,45,46)$ (Figure 2), chronic cough (32-34) or chronic airflow limitation (7). Sputum examination has illustrated the kinetics of change in sputum eosinophilia with changes in prednisone treatment. During severe exacerbations of asthma, the improvement in sputum eosinophils lags behind improvement in $\mathrm{FEV}_{1}$ (6). Persistence of sputum eosinophilia has been observed in subjects whose symptoms and $\mathrm{FEV}_{1}$ seem to be controlled (46). In these individuals, the sputum eosinophilia can be reversed by higher doses of steroid, but the clinical relevance of this still needs investigation (47). When prednisone is reduced in patients who are prednisone-dependent (37), and when inhaled steroid is reduced in inhaled steroid-dependent patients (48), sputum eosinophilia recurs before there is worsening of symptoms, FEV 1 or PEF (Table 2). The serial observations raise the possibility that the control of sputum eosinophilia will produce better outcomes than control of symptoms and $\mathrm{FEV}_{1}$. This hypothesis deserves investigation.

In contrast, it appears that when there is no eosinophilia in asthma, chronic cough or chronic airflow limitation, patients fail to respond clinically to corticosteroid treatment $(6,7,49,50)$. Such noneosinophilic (usually neutrophilic) exacerbations of asthma seem to be steroid resistant. This observation needs to be confirmed and alternative treatment for the exacerbations investigated.

Sputum examination has also helped increase the knowledge of the actions of drugs used in the treatment of asthma. Salmeterol was shown to have no effect on sputum eosino-

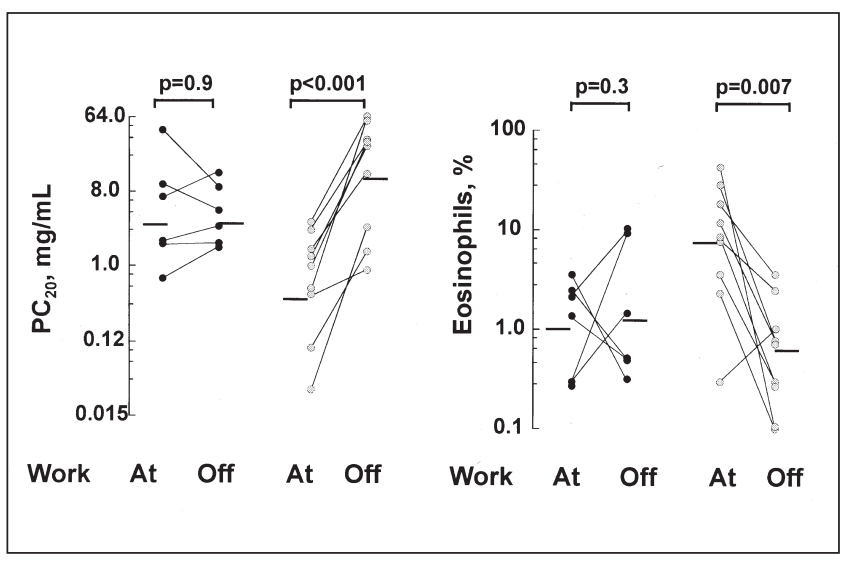

Figure 3) Changes in provocation concentration of methacholine to cause a fall in $\mathrm{FEV}$ of $20 \%\left(P C_{20}\right)$ (left) and sputum eosinophils (right) between periods at and away from work in patients with occupational asthma (open circles) and nonoccupational asthma (55) (closed circles). Horizontal bars show the median eosinophils percentage and the geometric mean $P_{2} C_{20}$. Patients with occupational asthma diagnosed clinically by a fourfold increase in $P_{2} C_{20}$ after four weeks away from work also had a fall in of percentage eosinophils

philia (51) and to mask slightly the clinical effects of developing sputum eosinophilia (52), thus delaying the recognition of a clinical exacerbation. Montelukast (Singulair, Merck Frosst Canada) has been shown to reduce sputum eosinophils, although the magnitude of its effect and the clinical relevance still need investigation (53).

\section{THE PLACE OF SPUTUM EXAMINATION IN PRACTICE}

Research observations indicate that it can be difficult for physicians to recognize the presence or type of airway inflammation (54). The significance of this in relation to the effects of treatment needs further investigation, but observations do identify places in practice where sputum examination can be useful.

- When patients present with a chronic cough, sputum examination can be helpful to diagnose eosinophilic bronchitis, which responds to corticosteroid treatment. The presence of sputum eosinophilia indicates a need to search for a causal allergen or occupational chemical sensitizer, and for initial treatment with avoidance strategies and corticosteroid. If sputum eosinophilia is not present, other causes of the chronic cough and other treatment should be considered first.

- Sputum examination provides an additional objective measurement to diagnose occupational asthma. Occupational asthma is usually caused by allergens or occupational chemical sensitizers to which the person has become sensitized, and is associated with sputum eosinophilia (55) (Figure 3). Hence, when the person is at work, sputum eosinophilia develops, and, when the patient is away from work for a period, the 
eosinophilia resolves. The recent description of work-related neutrophilic exacerbations of asthma raises the question of how often this occurs and in what situations $(43,44)$.

- When there is difficulty controlling asthma, sputum cell counts can indicate whether the patient is prednisone-dependent (37), or whether failure to respond to prednisone might be due to a noneosinophilic exacerbation of asthma or other disease (50). The persistence of sputum eosinophilia despite high doses of corticosteroid treatment should raise the possibility of patient noncompliance with treatment.

- In patients with moderate to severe chronic airflow limitation, sputum eosinophilia predicts benefit from corticosteroid treatment (7).

- The value of sputum examination to monitor anti-inflammatory treatment requires investigation (56).

\section{PROVISION OF SPUTUM CELL COUNTS IN PRACTICE}

The provision of reliable sputum cell counts in practice is problematic. There is no billing system (public or private) to cover the cost of sputum induction or appropriate sputum examination.

\section{REFERENCES}

1. Hargreave FE, Pizzichini E, Pizzichini MM. Assessment of airway inflammation. In: Barnes P, Grunstein M, Leff A, Woolcock A, eds. Asthma, vol 2. Philadelphia: Lippincott-Raven, 1997:1433-50.

2. Pin I, Gibson PG, Kolendowicz R, et al. Use of induced sputum cell counts to investigate airway inflammation in asthma. Thorax 1992;47:25-9.

3. Efthimiadis A, Pizzichini E, Pizzichini MM, Hargreave FE. Sputum examination for indices of airway inflammation: laboratory procedures. Lund: Astra Draco AB, 1997. Distributed through the Canadian Thoracic Society.

4. Wong HH, Fahy JV. Safety of one method of sputum induction in asthmatic subjects. Am J Respir Crit Care Med 1997; 156:299-303.

5. de la Fuente P, Romagnoli M, Godard P, Bousquet J, Chanez P. Safety of inducing sputum in patients with asthma of varying severity. Am J Respir Crit Care Med 1998;157:1127-30.

6. Pizzichini MM, Pizzichini E, Clelland L, et al. Sputum in severe exacerbations of asthma: kinetics of inflammatory indices after prednisone treatment. Am J Respir Crit Care Med 1997;155:1501-8.

7. Pizzichini E, Pizzichini MM, Gibson P, et al. Sputum eosinophilia predicts benefit from prednisone in smokers with chronic obstructive bronchitis. Am J Respir Crit Care Med 1998;158:1511-7.

8. Kips JC, Peleman RA, Rauwels RA. Methods of examining induced sputum: do differences matter? Eur Respir J 1998;11:529-33.

9. Pizzichini E, Pizzichini MM, Efthimiadis A, et al. Indices of airway inflammation in induced sputum: reproducibility and validity of cell and fluid phase measurements. Am J Respir Crit Care Med 1996;154:308-17

10. Pizzichini MM, Popov T, Efthimiadis A, et al. Spontaneous and induced sputum to measure indices of airway inflammation. Am J Respir Crit Care Med 1996;154:866-9.

11. Pizzichini E, Pizzichini MM, Efthimiadis A, Hargreave FE, Dolovich J. Measurement of inflammatory indices in induced sputum: effects of selection of sputum to minimize salivary contamination. Eur Respir J 1996;9:1174-80.

12. Ward R, Woltmann G, Wardlaw AJ, Pavord ID. Between-observer repeatability of sputum differential cell counts. Influence of cell viability and squamous cell contamination. Clin Exp Allergy 1999;29:248-52.
The procedure for sputum induction is not dissimilar to the procedure for a methacholine inhalation test. However, it would be inappropriate to perform sputum induction if it is not backed up by reliable sputum examination. The latter needs to be performed by hematologically trained, registered technologists and to involve ongoing quality control checks. The procedure can be performed by a hematology laboratory, but this will likely be difficult to arrange when health care funds to hospitals have been reduced. An alternative is to employ a technologist to perform sputum examination in the pulmonary function laboratory.

For the moment, in Hamilton, Ontario, we have introduced sputum induction by registered pulmonary function technologists in the pulmonary function laboratory and reliable sputum examination by research staff. The service is available at one centre in the city. Other physicians in the city and surrounding areas can refer patients for the procedures as for any other pulmonary function test.

Discussions need to be undertaken with medical insurance providers to introduce an appropriate billing system to allow the procedures to be made available in other areas of Canada.

ACKNOWLEDGEMENTS: I thank Lori Burch for typing the manuscript, Ann Efthimiadis for providing Figure 1, and Marcia and Emilia Pizzichini for Figures 2 and 3.

13. Gauvreau GM, Doctor J, Watson RM, Jordana M, O’Byrne PM. Effects of inhaled budesonide on allergen-induced airway responses and airway inflammation. Am J Respir Crit Care Med 1996;154:1267-71.

14. Fahy JV, Wong H, Liu J, Boushey HA. Comparison of samples collected by sputum induction and bronchoscopy from asthmatic and healthy subjects. Am J Respir Crit Care Med 1995;152:53-8.

15. Maestrelli P, Saetta M, Di Stefano A, et al. Comparison of leukocyte counts in sputum, bronchial biopsies and bronchoalveolar lavage. Am J Respir Crit Care Med 1995;152:1926-31.

16. Grootendorst DC, Sont JK, Willems LNA, et al. Comparison of inflammatory cell counts in asthma: induced sputum vs bronchoalveolar lavage and bronchial biopsies. Clin Exp Allergy 1997;27:769-79.

17. Keatings VM, Evans DJ, O’Connor BJ, Barnes PJ. Cellular profiles in asthmatic airways: a comparison of induced sputum, bronchial washings, and bronchoalveolar lavage fluid. Thorax 1997;52:372-4.

18. Pizzichini E, Pizzichini MM, Kidney JC, et al. Induced sputum, bronchoalveolar lavage and blood from mild asthmatics: inflammatory cells, lymphocyte subsets and soluble markers compared. Eur Respir J 1998;11:828-34

19. Pizzichini E, Pizzichini MM, Efthimiadis A, Dolovich J, Hargreave FE. Measuring airway inflammation in asthma: eosinophils and eosinophilic cationic protein in induced sputum compared with peripheral blood. J Allergy Clin Immunol 1997;99:539-44.

20. Djukanovic R, Homeyard S, Gratziou C, et al. The effect of treatment with oral corticosteroids on asthma symptoms and airway inflammation. Am J Respir Crit Care Med 1997;155:826-32.

21. Scadding JG. Definition and clinical categorization. In: Clark TJH, Godfrey S, eds. Asthma. London: Chapman and Hall, 1983:1-11.

22. De Monchy JGR, Kauffman HF, Venge P, et al. Bronchoalveolar eosinophilia during allergen-induced late asthmatic reactions. Am Rev Respir Dis 1985;131:373-6.

23. Maestrelli P, Calcagni PG, Saetta MP, et al. Sputum eosinophilia after asthmatic responses induced by isocyanates in sensitized subjects. Clin Exp Allergy 1994;24:29-34.

24. Lemière C, Pizzichini MMM, Balkissoon R, et al. Diagnosing occupational asthma: use of induced sputum. Eur Respir J 1999;13:482-8. 
25. Gibson PG, Wong BJ, Hepperle MJ, et al. A research method to induce and examine a mild exacerbation of asthma by withdrawal of inhaled corticosteroid. Clin Exp Allergy 1992;22:525-32.

26. Keatings VM, Barnes PJ. Granulocyte activation markers in induced sputum: comparison between chronic obstructive pulmonary disease, asthma, and normal subjects. Am J Respir Crit Care Med 1997;155:449-53.

27. Pizzichini MM, Pizzichini E, Efthimiadis A, et al. Asthma and natural colds: inflammatory indices in induced sputum. A feasibility study. Am J Respir Crit Care Med 1998;158:1178-84.

28. Nightingale JA, Rogers DF, Hart LA, Kharitonov SA, Chung K, Barnes PJ. Effect of inhaled endotoxin on induced sputum in normal, atopic, and atopic asthmatic subjects. Thorax 1998;53:563-71.

29. Fahy JV, Wong HH, Liu JT, Boushey HA. Analysis of induced sputum after air and ozone exposures in healthy subjects. Environ Res 1995;70:77-83.

30. Pizzichini MM, Pizzichini E, Efthimiadis A, et al. Markers of inflammation in induced sputum in acute bronchitis caused by Chlamydia pneumoniae. Thorax 1997;52:929-31.

31. Berlyne, GS, Efthimiadis A, Hussack P, Groves D, Dolovich J, Hargreave FE. A comparison of macroscopic and microscopic sputum analysis in asthma. Clin Invest Med 1998:S103. (Abst)

32. Gibson PG, Dolovich J, Denburg J, Ramsdale EH, Hargreave FE. Chronic cough: eosinophilic bronchitis without asthma. Lancet 1989;i:1346-8.

33. Gibson PG, Hargreave FE, Girgis-Gabardo A, Morris M. Denburg JA, Dolovich J. Chronic cough with eosinophilic bronchitis and examination for variable airflow obstruction and response to corticosteroid. Clin Exp Allergy 1995;25:127-32.

34. Gibson PG, Zlatic K, Scott J, Sewell W, Woolley K, Saltos N. Chronic cough resembles asthma with IL-5 and granulocyte-macrophage colony-stimulating factor gene expression in bronchoalvaolar cells. J Allergy Clin Immunol 1998;101:320-6.

35. Lemière C, Efthimiadis A, Hargreave FE. Occupational eosinophilic bronchitis without asthma: an unknown occupational airway disease. J Allergy Clin Immunol 1997;100:852-3.

36. Wong AG, Pavord I, Sears MR, Hargreave FE. A case for serial examination of sputum inflammatory cells. Eur Respir J 1996;9:2174-5.

37. Pizzichini MM, Pizzichini E, Clelland L, et al. Prednisone dependent asthma: inflammatory indices in induced sputum. Eur Respir J 1999;13:15-21.

38. Crimi E, Spanevello A, Neri M, Ind PW, Rossi GA, Brusasco V. Dissociation between airway inflammation and airway hyperresponsiveness in allergic asthma. Am J Respir Crit Care Med 1998;157:4-9.

39. Kidney JC, Wong AG, Efthimiadis A, et al. Elevated B cells in sputum of asthmatics: close correlation with eosinophils. Am J Respir Crit Care Med 1996;153:540-4.

40. Turner MO, Hussack P, Sears MR, Dolovich J, Hargreave FE. Exacerbations of asthma without sputum eosinophilia. Thorax 1995;50:1057-61.
41. Fahy JV, Kim KW, Liu J, Boushey HA. Prominent neutrophilic inflammation in sputum from subjects with asthma exacerbation. J Allergy Clin Immunol 1995;95:843-52.

42. Sur S, Crotty TB, Kephart GM, et al. Sudden-onset fatal asthma. A distinct entity with few eosinophils and relatively more neutrophils in the airway submucosa? Am Rev Respir Dis 1993;148:713-9.

43. Park HS, Jung KS, Hwang SC, Nahm DH, Yim HE. Neutrophil infiltration and release of IL-8 in airway mucosa from subjects with grain dust-induced occupational asthma. Clin Exp Allergy 1998;287:24-30.

44. Leigh R, Hargreave FE. Occupational neutrophilic asthma. Can Respir J 1999;6:205-208.

45. Claman DM, Boushey HA, Liu J, Wong H, Fahy JV. Analysis of induced sputum to examine the effects of prednisone on airway inflammation in asthmatic subjects. J Allergy Clin Immunol 1994;94:861-9.

46. Fahy JV, Boushey HA. Effect of low-dose beclomethasone dipropionate on asthma control and airway inflammation. Eur Respir J 1998;11:1240-7.

47. Jatakanon A, Kharitonov S, Lim S, Barnes PJ. Effect of differing doses of inhaled budesonide on markers of airway inflammation in patients with mild asthma. Thorax 1999;54:108-14.

48. Belda J, Kamada D, Lemiére C, Efthimiadis A, Hargreave FE. The kinetics of clinical and inflammatory indices during an exacerbation of asthma induced by inhaled steroid reduction. Am J Respir Crit Care Med 1999;159:A123. (Abst)

49. Pizzichini MM, Pizzichini E, Parameswaran K, et al. Non-asthmatic chronic cough: no effect of treatment with an inhaled corticosteroid in patients without sputum eosinophilia. Can Respir J 1999. (In press)

50. Parameswaran K, Pizzichini MM, Li D, Pizzichini E, Jeffery PK, Hargreave FE. Serial sputum cell counts in the management of chronic airflow limitation. Eur Respir J 1998;11:1405-8.

51. Turner MO, Johnston PR, Pizzichini E, Pizzichini MM, Hargreave FE. Anti-inflammatory effects of salmeterol compared with beclomethasone in mild exacerbations of asthma: a randomized, placebo controlled trial. Can Respir J 1998;5:261-8.

52. Mcivor RA, Pizzichini E, Turner MO, Hussack P, Hargreave FE, Sears MR. Potential masking effects of salmeterol on airway inflammation in asthma. Am J Respir Crit Care Med 1998;158:924-30.

53. Pizzichini E, Leff JA, Reiss TF, et al. Montelukast, a leukotriene receptor antagonist, reduces airway eosinophilic inflammation in asthmatic patients: a randomized, controlled trial. Eur Respir J 1999. (In press)

54. Parameswaran K, Pizzichini E, Hussack P, Pizzichini MM, Efthimiadis A, Hargreave FE. Clinical judgement of airway inflammation versus sputum cell counts in asthma. Clin Invest Med 1998;21(Suppl):S102. (Abst)

55. Lemière C, Pizzichini MMM, Balkissoon R, et al. Diagnosing occupational asthma: use of induced sputum. Eur Respir J 1998;13:482-8.

56. Magnussen $\mathrm{H}, \mathrm{Holz} \mathrm{O}$, Monitoring airwat inflammation in asthma induced sputum. Eur Respir J 1999;13:5-7. 


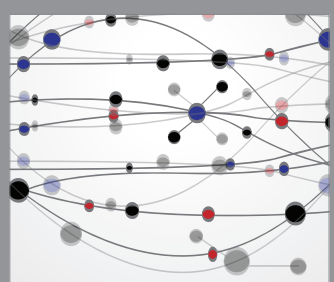

The Scientific World Journal
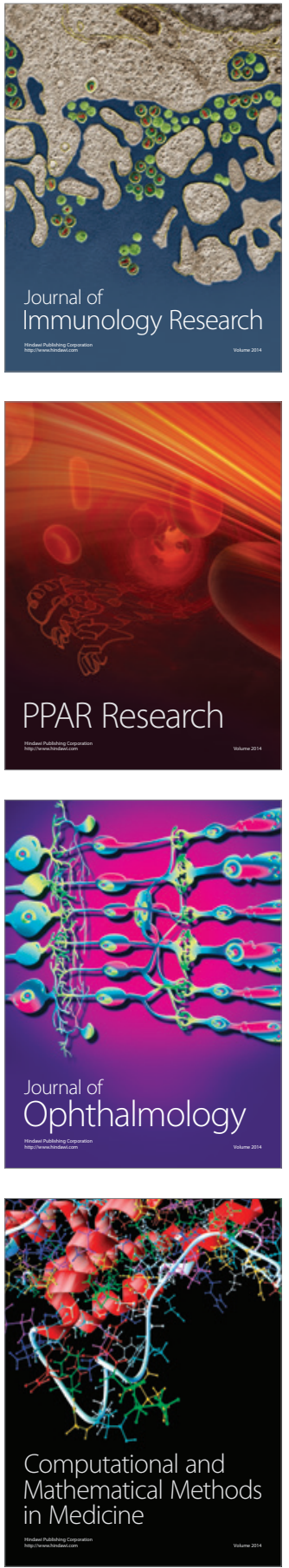

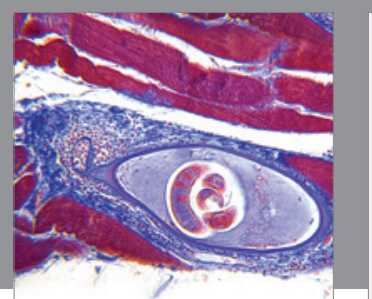

Gastroenterology Research and Practice

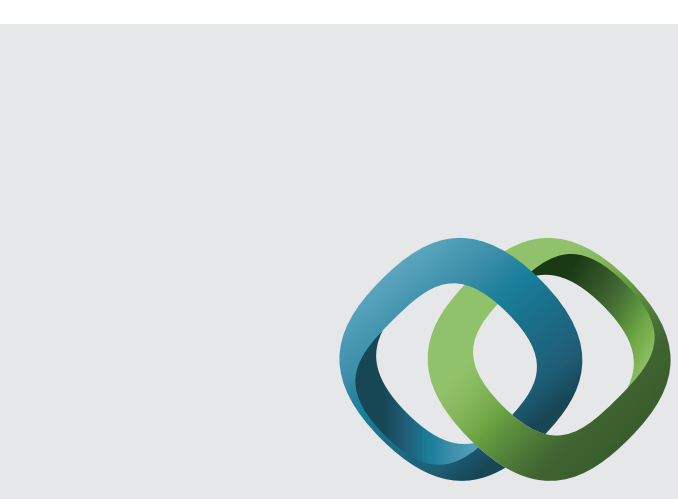

\section{Hindawi}

Submit your manuscripts at

http://www.hindawi.com
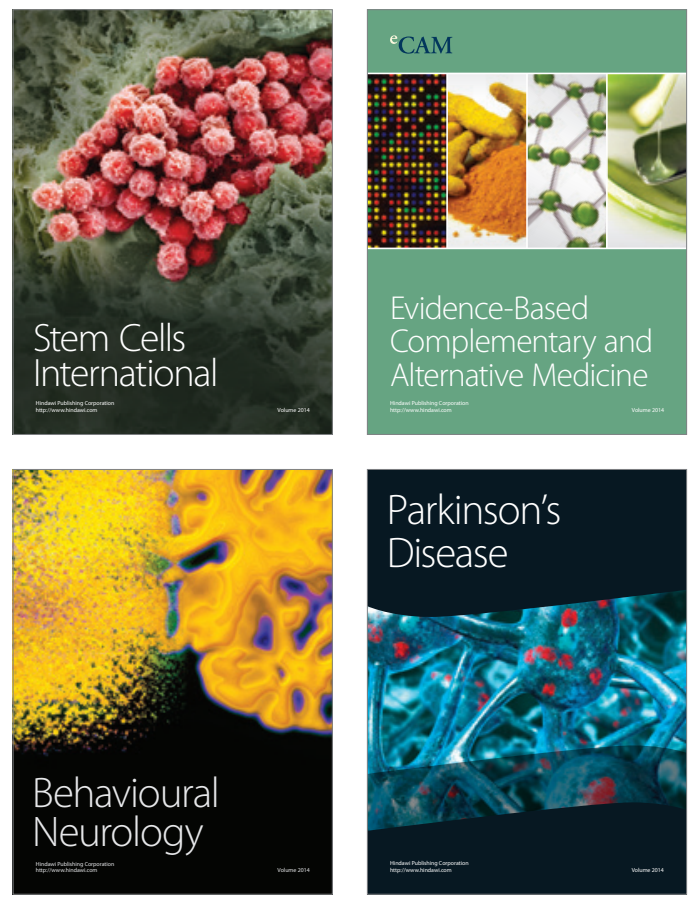
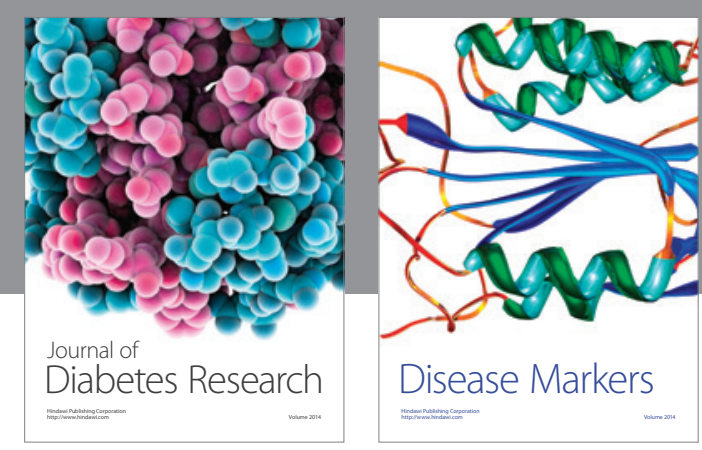

Disease Markers
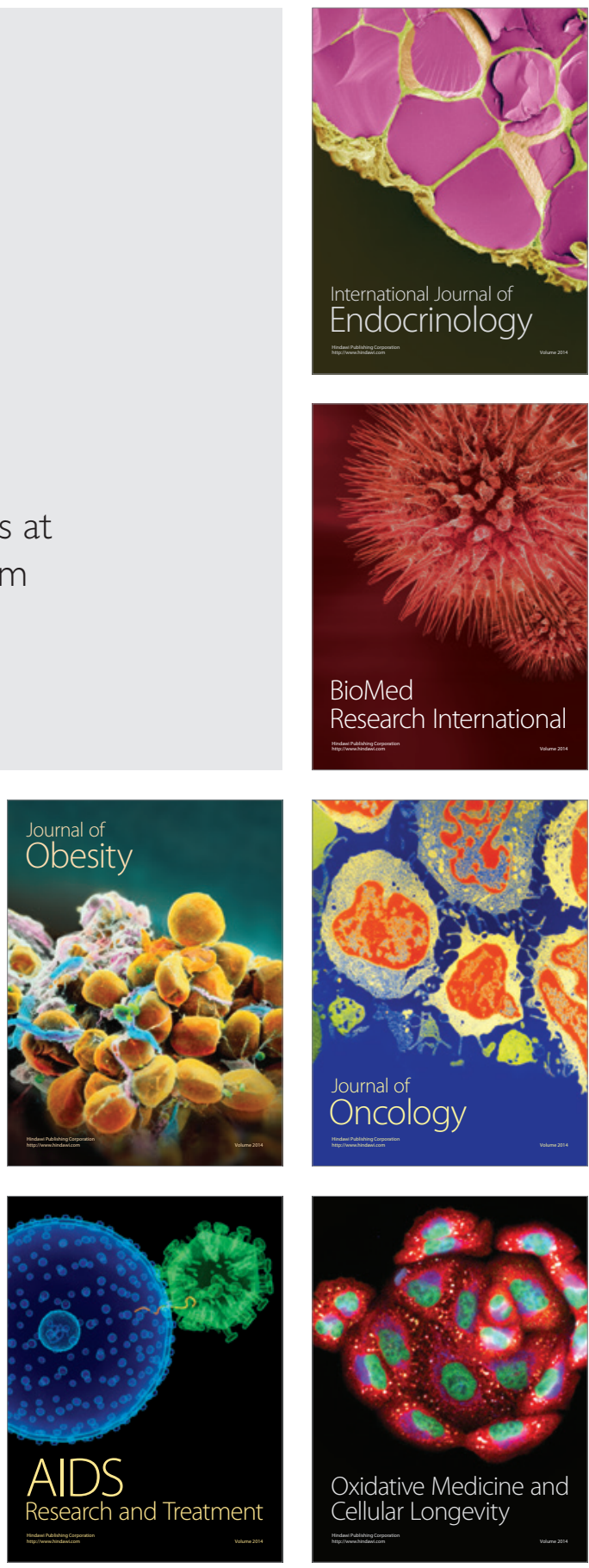